\title{
The Pandemic Brain: neuroinflammation in healthy, non-infected individuals during the COVID-19 pandemic
}

Ludovica Brusaferri ${ }^{1}$, Zeynab Alshelh ${ }^{1}$, Daniel Martins ${ }^{3,4}$, Minhae Kim ${ }^{1}$, Akila Weerasekera ${ }^{1}$, Hope Housman ${ }^{1}$, Erin J. Morrisey ${ }^{1}$, Paulina C. Knight ${ }^{1}$, Kelly A. Castro-Blanco ${ }^{1}$, Daniel S. Albrecht ${ }^{1}$, Chieh-En Tseng ${ }^{1}$, Nicole R. Zürcher ${ }^{1}$, Eva-Maria Ratai ${ }^{1}$, Oluwaseun JohnsonAkeju $^{1,2}$, Nathaniel D. Mercaldo ${ }^{1}$, Nouchine Hadjikhani ${ }^{1,6}$, Mattia Veronese ${ }^{3,4,5}$, Federico Turkheimer ${ }^{3,4}$, Bruce R. Rosen ${ }^{1}$, Jacob M. Hooker ${ }^{1}$, Marco L. Loggia ${ }^{1,2}$

${ }^{1}$ Athinoula A. Martinos Center for Biomedical Imaging, Department of Radiology, Massachusetts General Hospital, Harvard Medical School, Charlestown, MA, USA

${ }^{2}$ Department of Anesthesia, Critical Care \& Pain Medicine, Massachusetts General Hospital, Harvard Medical School, Boston, MA, USA

${ }^{3}$ Department of Neuroimaging, Institute of Psychiatry, Psychology \& Neuroscience, King's College London, De Crespigny Park, SE5 8AF, London, UK

${ }^{4}$ NIHR Maudsley Biomedical Research Centre, De Crespigny Park, Denmark Hill, London, SE5 $8 \mathrm{AF}, \mathrm{UK}$

${ }^{5}$ Department of Information Engineering, University of Padua, Padua, Italy

${ }^{6}$ Sahlgrenska Academy, University of Gothenburg, Gothenburg, Sweden 


\section{Summary}

\section{Background}

The impact of COVID-19 on human health extends beyond the morbidity and death toll directly caused by the SARS-CoV-2 virus. In fact, accumulating evidence indicates a global increase in the incidence of fatigue, brain fog and depression, including among non-infected, since the pandemic onset. Motivated by previous evidence linking those symptoms to neuroimmune activation in other pathological contexts, we hypothesized that subjects examined after the enforcement of lockdown/stay-at-home measures would demonstrate increased neuroinflammation.

\section{Methods}

We performed simultaneous brain Positron Emission Tomography / Magnetic Resonance Imaging in healthy volunteers either before $(n=57)$ or after $(n=15)$ the 2020 Massachusetts lockdown, using $\left[{ }^{11} \mathrm{C}\right] \mathrm{PBR} 28$, a radioligand for the glial marker $18 \mathrm{kDa}$ translocator protein (TSPO). First, we compared $\left[{ }^{11} \mathrm{C}\right] \mathrm{PBR} 28$ signal across pre- and post-lockdown cohorts. Then, we evaluated the link between neuroinflammatory signals and scores on a questionnaire assessing mental and physical impacts of the pandemic. Further, we investigated multivariate associations between the spatial pattern of $\left[{ }^{11} \mathrm{C}\right] \mathrm{PBR} 28$ post-lockdown changes and constitutive brain gene expression in post-mortem brains (Allen Human Brain Atlas). Finally, in a subset ( $\mathrm{n}=13$ prelockdown; $n=11$ post-lockdown), we also used magnetic resonance spectroscopy to quantify brain (thalamic) levels of myoinositol (mIns), another neuroinflammatory marker. 


\section{Findings}

Both $\left[{ }^{11} \mathrm{C}\right] \mathrm{PBR} 28$ and mIns signals were overall stable pre-lockdown, but markedly elevated after lockdown, including within brain regions previously implicated in stress, depression and "sickness behaviors". Moreover, amongst the post-lockdown cohort, subjects endorsing higher symptom burden showed higher $\left[{ }^{11} \mathrm{C}\right] \mathrm{PBR} 28$ PET signal compared to those reporting little/no symptoms. Finally, the post-lockdown $\left[{ }^{11} \mathrm{C}\right] \mathrm{PBR} 28$ signal changes were spatially aligned with the constitutive expression of several genes highly expressed in glial/immune cells and/or involved in neuroimmune signaling.

\section{Interpretation}

Our results suggest that pandemic-related stressors may have induced sterile neuroinflammation in healthy individuals that were not infected with SARS-CoV-2. This work highlights the possible impact of the COVID-19 pandemic-related lifestyle disruptions on human brain health.

\section{Funding}

R01-NS094306-01A1, R01-NS095937-01A1, R01-DA047088-01, The Landreth Family Foundation. 
medRxiv preprint doi: https://doi.org/10.1101/2021.09.21.21263740; this version posted September 27, 2021. The copyright holder for this

It is made available under a CC-BY-NC-ND 4.0 International license .

\section{Introduction}

Beyond the staggering number of infections and deaths, the Coronavirus Disease 2019 (COVID-19) pandemic has caused lifestyle, societal, and other disruptions, impacting the lives of a large swath of the world population in multiple ways. For instance, behavioral data have shown that symptoms of psychological distress have increased considerably in the United States since the enforcement of lockdown/stay-at-home measures (e.g., April-June of 2020, compared to the same period in 2019) $)^{1}$. Likewise, an increased prevalence of fatigue, dyscognition (i.e., "brain fog”) and other symptoms has been reported (including among the non-infected). As such, the scientific and medical communities are urgently calling for studies promoting a better understanding of the effects of the pandemic on brain and mental health. ${ }^{2-4}$

While the mechanisms underlying the non-virally mediated effects of the COVID-19 pandemic on brain health are currently unknown, we hypothesized that an elevation in neuroinflammatory responses might play a role. In fact, exposure to social stressors, including social isolation (a state experienced by many during lockdown), has been previously linked to elevations in serum levels of pro-inflammatory cytokines ${ }^{5}$ and activation of brain glial cells, ${ }^{6,7}$ involving mechanisms largely overlapping with those observed during infection-induced inflammation. ${ }^{8}$ Such "sterile" forms of (neuro)inflammation -much like their pathogen-associated counterparts- have been linked to produce a constellation of "sickness behaviors", including fatigue, depressive symptoms, social withdrawal, etc. ${ }^{9,10}$ Indeed, sterile-(neuro)inflammation is thought to be a key neurobiological process in the pathophysiology of mood disorders. ${ }^{11-13}$ Notably, elevations in (neuro)inflammatory markers have also been measured in patients suffering from fibromyalgia, ${ }^{14}$ myalgic encephalomyelitis / chronic fatigue syndrome, ${ }^{15}$ Gulf War Illness ${ }^{16}$ or insomnia. ${ }^{17}$ These conditions are characterized by abnormal fatigue, brain fog and/or other 
medRxiv preprint doi: https://doi.org/10.1101/2021.09.21.21263740; this version posted September 27, 2021. The copyright holder for this

It is made available under a CC-BY-NC-ND 4.0 International license .

psychological symptoms which have been increasingly documented during the pandemic. Thus, results from both clinical and preclinical literature raise the possibility that neuroinflammation might be a potential mechanism underlying the symptoms experienced during the pandemic by healthy individuals that were not infected by SARS-CoV-2.

To test this hypothesis, we conducted a retrospective analysis of advanced, multimodal $\left[{ }^{11} \mathrm{C}\right] \mathrm{PBR} 28$ Positron Emission Tomography/Magnetic Resonance (PET/MR) imaging data collected at the A. A. Martinos Center for Biomedical Imaging from 2012 to 2021. Specifically, we hypothesized that, after lockdown, subjects would demonstrate increased brain levels of the 18 $\mathrm{kDa}$ translocator protein (TSPO), ${ }^{18}$ and myoinositol (mIns), ${ }^{19}$ two putative glial markers that can be detected with PET and MR spectroscopy, respectively. In order to assess the clinical significance of our findings, we performed a preliminary investigation of the link between neuroinflammatory signals and scores on a questionnaire assessing mental and physical impacts of the pandemic. Finally, to understand the genetic underpinnings of our imaging results, we evaluated their spatial association with constitutive brain gene expression in post-mortem brains (Allen Human Brain Atlas). ${ }^{20}$

\section{Methods}

This research study was conducted at the Athinoula A. Martinos Center for Biomedical Imaging, Massachusetts General Hospital. Data were pooled for several protocols, which were approved by the Partners Healthcare / Mass General Brigham Institutional Review Board. All participants gave written informed consent at the time of their screening. 
medRxiv preprint doi: https://doi.org/10.1101/2021.09.21.21263740; this version posted September 27, 2021. The copyright holder for this preprint (which was not certified by peer review) is the author/funder, who has granted medRxiv a license to display the preprint in perpetuity.

It is made available under a CC-BY-NC-ND 4.0 International license .

\section{Study design and participants}

We conducted a retrospective brain imaging study of healthy individuals, originally enrolled as control subjects for various completed or ongoing, research studies investigating the role of neuroinflammation in various disorders.

In total, this study included fifty-seven 'pre-lockdown' datasets ( $\mathrm{HC}_{\mathrm{PRE}}$, acquired between

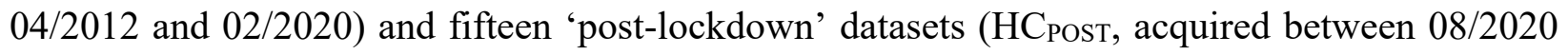
and 07/2021) (Suppl. Figure 1). For twenty-two subjects included in the $\mathrm{HC}_{\mathrm{PRE}}$ group, a second dataset was available, which was used in this study for support/sensitivity analyses (see Appendix). Of note, two participants were scanned before and after lockdown, thus contributing to data in both $\mathrm{HC}_{\mathrm{PRE}}$ and $\mathrm{HC}_{\mathrm{POST}}$ groups; of those, one subject was scanned before (September 2016) and after (October 2020) lockdown in the same scanner (Scanner 1), allowing us for an exploratory investigation of pre- vs post-lockdown within-subject effects.

All subjects in the $\mathrm{HC}_{\mathrm{POST}}$ cohort had a negative COVID-19 antibody test (Elecsys ${ }^{\circledR}$ AntiSARS-CoV-2, Roche Diagnostics; 99.81\% accuracy; 95\% confidence interval (CI): 99.65-99.1) at the time of the scan. No COVID-19 antibody testing was available for any of the $\mathrm{HC}_{\mathrm{PRE}}$ participants.

Demographics for the participants used in the PET and ${ }^{1} \mathrm{H}-\mathrm{MRS}$ analyses are displayed in Tables 1 and 2, respectively. 
medRxiv preprint doi: https://doi.org/10.1101/2021.09.21.21263740; this version posted September 27, 2021. The copyright holder for this preprint (which was not certified by peer review) is the author/funder, who has granted medRxiv a license to display the preprint in perpetuity.

It is made available under a CC-BY-NC-ND 4.0 International license .

\section{Data acquisition and processing}

During an initial screening visit, participants were consented, and genotyped for the Ala147Thr polymorphism in the TSPO gene, which is known to affect binding affinity for several TSPO radioligands, including $\left[{ }^{11} \mathrm{C}\right] \mathrm{PBR} 28 .^{21}$ Individuals with the Ala/Ala or Ala/Thr genotypes (predicted high- and mixed-affinity binders -HABs and MABs-, respectively) were included, and the genotype was modeled as a covariate in the statistical design (see below). Individuals with the Thr/Thr genotype (predicted "low-affinity binders") were excluded at the time of the screening and therefore not represented in our dataset.

Dynamic PET/MR scans were performed with two different Siemens scanners: a 3T Tim Trio whole-body MRI with a dedicated brain PET insert (BrainPET; Scanner 1) and a 3T Verio whole-body, MRI whole-body PET tomograph (Biograph mMR; Scanner 2). Participants were injected with up to $\sim 15$ millicuries (mCi) $\left[{ }^{11} \mathrm{C}\right] \mathrm{PBR} 28$ as an intravenous bolus and dynamic PET was acquired as described in previous studies. ${ }^{12,16}\left[{ }^{11} \mathrm{C}\right] \mathrm{PBR} 28$ is a second-generation radioligand commonly used to image the glial marker TSPO for the study of neuroinflammation in various conditions. ${ }^{22}$ All participants were scanned for a time-period that included $\sim 60-90$ minutes postinjection (the framing window used in our PET analyses; see below). See Appendix for further details on PET data acquisition and processing.

SUV ratio (SUVR) images were obtained via intensity-normalization using the occipital cortex as a pseudo-reference region, as done in previous research. ${ }^{14,16}$ This region demonstrated no statistically significant group differences in mean SUV ( $\mathrm{p}=0.18$; GLM, correcting for age, scanner and genotype; see below), indicating that the use of this signal as a normalizing factor did not bias our results. To support findings from SUVR measurements, distribution volume (DVR) outcomes were determined using kinetic modeling in a subset of subjects for whom a 
medRxiv preprint doi: https://doi.org/10.1101/2021.09.21.21263740; this version posted September 27, 2021. The copyright holder for this

radiometabolite-corrected arterial input function was available $\left(\mathrm{n}=24 ; 16 \mathrm{HC}_{\mathrm{PRE}} ; 8 \mathrm{HC}_{\mathrm{POST}}\right)$, as described in the Appendix.

Simultaneously to the PET data collection, a subset (13 $\mathrm{HC}_{\mathrm{PRE}} ; 11 \mathrm{HC}$ POST) was also scanned with ${ }^{1} \mathrm{H}-\mathrm{MRS}$. Single voxel ${ }^{1} \mathrm{H}-\mathrm{MRS}$ was acquired from the left thalamus using a PRESS sequence with same parameters in both scanners $(\mathrm{TE}=30 \mathrm{~ms}, \mathrm{TR}=1.7 \mathrm{~s}$, bandwidth $=1.2 \mathrm{kHz}$, number of averages $=128$, sample points $=1024)$. See Appendix for further details on ${ }^{1} \mathrm{H}-\mathrm{MRS}$ data acquisition and processing. This technique allowed us to quantify the brain concentration of myoinositol (mIns), another putative glial marker, ${ }^{19}$ and -for reference- Creatine (Cr; a cellular energetic marker) and N-Acetyl Aspartate (NAA; a marker of neuronal integrity).

To interrogate the possible clinical significance of our results, we retrospectively administered a questionnaire assessing the impact of the COVID-19 pandemic on mental and physical well-being, specifically assessing mental/physical fatigue, dyscognition and mood alterations ( $\mathrm{n}=11$; See Appendix).

\section{Statistical analysis}

Descriptive summaries were computed by group ( $\left.\mathrm{HC}_{\mathrm{PRE}}, \mathrm{HC}_{\mathrm{POST}}\right)$. Continuous variables were summarized as mean and standard deviation (SD) and categorical variables were summarized as frequencies and percentages. Group differences in demographics were assessed with Student's t-tests for continuous variables (age, injected dose, weight) and Chi-Square $\left(\chi^{2}\right)$ tests for categorical variables (sex, TSPO polymorphism, scanner).

Covariate imbalance was assessed in all the analyses by adjusting for confounding variables but was also accounted for via matching (see Appendix). Specifically, given the 
medRxiv preprint doi: https://doi.org/10.1101/2021.09.21.21263740; this version posted September 27, 2021. The copyright holder for this preprint (which was not certified by peer review) is the author/funder, who has granted medRxiv a license to display the preprint in perpetuity.

It is made available under a CC-BY-NC-ND 4.0 International license .

significant difference in age across $\mathrm{HC}_{\mathrm{PRE}}$ and $\mathrm{HC}_{\mathrm{POST}}$ groups (Tables 1 and 2), we re-ran all group analyses using smaller subsets of $\mathrm{HC}_{\mathrm{PRE}}$ who were better demographically matched to the $\mathrm{HC}_{\mathrm{POST}}$ cohort (p’s $\geq 0.11$ ) (Suppl. Table 1 and 2).

Two sets of analyses were preformed to quantify the association between $\left[{ }^{11} \mathrm{C}\right] \mathrm{PBR} 28$ signal and group. First, pre- and post-lockdown $\left[{ }^{11} \mathrm{C}\right] \mathrm{PBR} 28$ signal was compared in a-priori region-of-interest (ROI) analysis, in areas previously associated with stress or depression: nucleus accumbens, ${ }^{23}$ hippocampus, ${ }^{7,24}$ thalamus, ${ }^{25}$ and anterior cingulate cortex (ACC). ${ }^{12}$ Labels from the Harvard-Oxford Cortical and Subcortical Structural Atlas (Center for Morphometric Analyses, http://www.cma.mgh.harvard.edu/fsl_atlas.html) were used to determine these ROIs. For each ROI, a General Linear Model (GLM) was used to quantify the association between PET signal and group while adjusting for age, TSPO binding affinity, and scanner.

Second, we performed a non-parametric voxel-wise analysis of the whole brain to evaluate the presence of group differences in the $\left[{ }^{11} \mathrm{C}\right] \mathrm{PBR} 28$ signal beyond the constraint of our a priori ROIs. Group differences were assessed by using a permutation test (FSL randomise; 5000 permutations; cluster-forming threshold of $\mathrm{p}=0.01$; cluster size threshold of $\mathrm{p}=0.05$ ), again accounting for age, binding affinity, and scanner. Mindful of the relatively small sample size of the $\mathrm{HC}_{\text {POST }}$ cohort, we repeated this analysis with a more conservative cluster-forming threshold of $p=0.001$, to further reduce the likelihood of false positives. The resulting significant cluster (see Results) was parcellated by intersecting it with anatomical labels in standard space. From these parcels, the mean PET signal was extracted for visualization purposes, as well as correlational and support/sensitivity analyses (see below and Appendix).

In order to assess the link between neuroinflammation and clinical variables, we used GLM analyses to test for differences in $\left[{ }^{11} \mathrm{C}\right] \mathrm{PBR} 28$ signal between $\mathrm{HC}_{\text {POST }}$ subjects reporting higher vs 
medRxiv preprint doi: https://doi.org/10.1101/2021.09.21.21263740; this version posted September 27, 2021. The copyright holder for this preprint (which was not certified by peer review) is the author/funder, who has granted medRxiv a license to display the preprint in perpetuity.

It is made available under a CC-BY-NC-ND 4.0 International license .

lower symptom burden (mental/physical fatigue, dyscognition and mood alteration; see Appendix). These analyses were done using mean signal extracted from the cluster parcels obtained from the main analysis (Bonferroni-corrected for number of regions). Due to the smaller sample size of subjects completing the questionnaire $(n=11)$, the main model employed in these analyses included only TSPO genotype as a covariate.

To further corroborate the hypothesis that increased $\left[{ }^{11} \mathrm{C}\right] \mathrm{PBR} 28$ signal might reflect glial/neuroimmune activity, we performed imaging transcriptomics analyses of the statistical maps quantifying differences between $\mathrm{HC}_{\mathrm{PRE}}$ and $\mathrm{HC}_{\mathrm{POST}}$ cohorts. Specifically, given the spatial heterogeneity in the density of key players in the neuroimmune response across brain regions, we reasoned that if $\left[{ }^{11} \mathrm{C}\right] \mathrm{PBR} 28$ reflect global engagement of glial neuroinflammatory pathways, then regional vulnerability to $\left[{ }^{11} \mathrm{C}\right] \mathrm{PBR} 28$ increases between $\mathrm{HC}_{\mathrm{PRE}}$ and $\mathrm{HC}_{\mathrm{POST}}$ cohorts should follow the constitutive architecture of the neuroinflammatory machinery. Thus, genes positively correlated with $\left[{ }^{11} \mathrm{C}\right] \mathrm{PBR} 28$ changes across brain regions must be enriched for: 1) genes from biological pathways related to neuroimmune pathways and 2) genes highly expressed in microglia/astrocyte cells as key players of the neuroimmune response.

The Allen Human Brain Atlas (AHBA) was used to estimate whole-transcriptome gene expression in the 83 cortical and subcortical regions of the Desikan-Killiany (DK) atlas (Suppl. Figure 9). We then used partial least square regression (PLS) to investigate associations between the $\left[{ }^{11} \mathrm{C}\right] \mathrm{PBR} 28 \mathrm{HC}_{\mathrm{POST}}>\mathrm{HC}_{\mathrm{PRE}}$ contrast map (T-stat) and brain gene expression of 15,633 genes, retaining the component explaining the largest amount of variance above chance alone (PLS 1 ). Finally, we tested the list of genes ranked by the respective weights in $\mathrm{PLS}_{1}$ component for enrichment in genes from specific biological pathways and expressed in different brain cell types. See Appendix for further details on transcriptomic analysis. 
medRxiv preprint doi: https://doi.org/10.1101/2021.09.21.21263740; this version posted September 27, 2021. The copyright holder for this preprint (which was not certified by peer review) is the author/funder, who has granted medRxiv a license to display the preprint in perpetuity.

It is made available under a CC-BY-NC-ND 4.0 International license .

Finally, to assess the effect of the pandemic on a different putative neuroinflammation imaging marker, we analyzed ${ }^{1} \mathrm{H}-\mathrm{MRS}$ data using GLM to test for group differences in mIns while accounting for age and scanner as regressors of no interest. Group analyses were also conducted on the markers $\mathrm{Cr}$ and NAA, for reference.

Voxel-wise analyses were performed with FSL's FEAT GLM tool (www.fmrib.ox.ac.uk/fsl, version 5.0.10). Demographics, ROI PET and behavioral analyses were performed using Statistica (TIBCO Software Inc., v.13). Transcriptomic analyses were conducted using the Web-based gene set analysis toolkit (WebGestalt).

\section{Role of the funding source}

The funder had no role in the study design, data collection, data analysis, data interpretation, or writing of the report.

\section{Results}

Post-lockdown participants reported experiencing various symptoms since the onset of the pandemic, including mood alterations (54\%), mental (36\%) and physical (27\%) fatigue, and dyscognition (18\%). These symptoms were paralleled by a post-lockdown increase in $\left[{ }^{11} \mathrm{C}\right] \mathrm{PBR} 28$ signal, which was apparent in both ROI and voxelwise analyses (including in all support/sensitivity analyses performed).

The a priori ROI analyses (Figure 1) revealed that $\left[{ }^{11} \mathrm{C}\right] \mathrm{PBR} 28$ signal was higher in $\mathrm{HC}$ POST compared to $\mathrm{HC}_{\mathrm{PRE}}$ in all the ROI evaluated (p's $<0.05$ corrected). Whole-brain voxelwise 
analyses (Figure 2, Supp. Figure 2) confirmed the $\left[{ }^{11} \mathrm{C}\right] \mathrm{PBR} 28$ signal elevation in $\mathrm{HC}_{\text {POST }}$ cohort, identifying a large cluster encompassing both grey and white matter regions, including portions of the anatomical regions used as our a-priori ROIs as well as additional regions (precental, postcentral, superior, middle and inferior frontal gyri, precuneus, superior parietal lobule, anterior and posterior insula, amygdala, putamen, supplementary motor cortex, anterior, middle, posterior cingulate and subcallosal cortex; see Table 3). Notably, $\left[{ }^{11} \mathrm{C}\right] \mathrm{PBR} 28$ signal elevation in $\mathrm{HC}$ POST could be observed irrespective of scanner, age, genotype, sex, injected dose and body weight (see Appendix, Suppl. Figure 3). In all the evaluated sub-clusters, post-lockdown $\left[{ }^{11} \mathrm{C}\right] \mathrm{PBR} 28$ signal elevations were also confirmed by a different metric (DVR; $0.009 \leq \mathrm{p} \leq 0.04$ corrected; Suppl. Figure 4A), which was strongly correlated with SUVR ( $\geq 0.77 ; \mathrm{p} \leq 0.001$; Suppl. Figure 4B).

The results of the group analyses were replicated within-subject in the single participant scanned before and after lockdown in the same scanner. Indeed, this subject demonstrated widespread PET signal elevation in all tested areas (Figure 3A-B), with post-lockdown increases ranging up to $22.6 \%$ (Nucleus Accumbens).

Figure 4A and 4B display the PET signal over time (i.e., across subjects). Both plots are indicative of a constant trend for nearly a decade (as corroborated by time-stability and scan-rescan reliability tests; Appendix, Suppl. Figure 5A, Figure 5B), followed by a noticeable increase after lockdown.

When categorizing the $\mathrm{HC}_{\mathrm{POST}}$ subjects into higher and lower symptom burden, we found the PET signal in the IPS and precuneus to be associated with physical fatigue $(\mathrm{p}<0.01$ and $\mathrm{p}<0.05$ uncorrected, respectively), whereas the hippocampal PET signal was more closely linked to mental fatigue and mood alterations $(\mathrm{p}<0.01$ and $\mathrm{p}<0.05$ uncorrected, respectively) (see Figure 5). Of these results, the IPS-physical fatigue association remained statistically significant after correction 
medRxiv preprint doi: https://doi.org/10.1101/2021.09.21.21263740; this version posted September 27, 2021. The copyright holder for this preprint (which was not certified by peer review) is the author/funder, who has granted medRxiv a license to display the preprint in perpetuity.

It is made available under a CC-BY-NC-ND 4.0 International license .

for multiple comparisons. No association was found with dyscognition symptoms (although the very small sample size of participants reporting an increase in this symptom, $n=2$, rendered this analysis inconclusive).

Regional vulnerability to changes in $\left[{ }^{11} \mathrm{C}\right] \mathrm{PBR} 28$ signal between $\mathrm{HC}_{\mathrm{PRE}}$ and $\mathrm{HC}_{\mathrm{POST}}$ was predicted by regional variability in the human brain transcriptome: PLS $_{1}$ alone explained 37.33\% of variance in $\left[{ }^{11} \mathrm{C}\right] \mathrm{PBR} 28 \mathrm{~T}$-statistics (Suppl. Figure 10) and did so above chance $\left(\mathrm{p}_{\mathrm{SPATAL}}<\right.$ 0.01; see Appendix for details). As Figure 6A illustrates, $\mathrm{PLS}_{1}$ regional scores correlated positively with $\left[{ }^{11} \mathrm{C}\right] \mathrm{PBR} 28$ contrast map, i.e. genes with positive weights in $\mathrm{PLS}_{1}$ have higher-than-average expression where $\left[{ }^{11} \mathrm{C}\right] \mathrm{PBR} 28$ signal showed the largest post-lockdown increases and lower-thanaverage expression in regions with minimal changes. Among the genes with the highest $\mathrm{PLS}_{1}$ weights were AQP4 $\left(24^{\text {th }}\right.$ out of 15,633$)$ and CSF1R $\left(32^{\text {th }}\right)$, two genes strongly expressed in glial cells (Figure 6B), as well as CCR1, a monocyte marker. Indeed, our analyses revealed significant enrichment for genes: i) highly expressed in glial cells, including astrocytes and microglia as first and second hits respectively (Figure 6C and Supplementary Table 3); ii) belonging to several biological pathways related to the neuroinflammatory response (Supplementary Table 4).

Paralleling the $\left[{ }^{11} \mathrm{C}\right] \mathrm{PBR} 28 \mathrm{PET}$ results, the subset of $\mathrm{HC}_{\mathrm{POST}}$ cohort with ${ }^{1} \mathrm{H}-\mathrm{MRS}$ data also demonstrated significantly higher thalamic concentration of the glial metabolite mIns, measured using ${ }^{1} \mathrm{H}-\mathrm{MRS}$, compared to the $\mathrm{HC}_{\mathrm{PRE}}$ cohort $(\mathrm{p}<0.01)$; Figure $\left.7 \mathrm{~A}\right)$, particularly in the first months post-lockdown (Figure 7B). The post-lockdown increases in mIns concentration appeared to be metabolite-specific, since group differences in $\mathrm{Cr}$ (a cellular energetic marker) and NAA (a marker of neuronal integrity) concentrations were not statistically significant ( $>0.2$ ) (Suppl. Figure 7). No significant correlation was found between thalamic mIns and SUVR signal $(p=0.31)$. 
medRxiv preprint doi: https://doi.org/10.1101/2021.09.21.21263740; this version posted September 27, 2021. The copyright holder for this

It is made available under a CC-BY-NC-ND 4.0 International license .

Ancillary analyses replicated both $\left[{ }^{11} \mathrm{C}\right] \mathrm{PBR} 28$ and ${ }^{1} \mathrm{H}-\mathrm{MRS}$ results when 1) including only a subset of $\mathrm{HC}_{\mathrm{PRE}}$ participants better demographically matched to $\mathrm{HC}_{\mathrm{POST}}$ cohort (Appendix, Suppl. Figure 6A, Figure 8A); 2) using alternate datasets (i.e., datasets collected in individuals scanned twice and not used in the primary analyses; Appendix, Suppl. Figure 6B, Figure 8B); or 3) excluding subjects who had received the vaccine against the SARS-CoV-2 virus (Appendix, Suppl. Figure 6C, Figure 8C).

\section{Discussion}

This study provides novel evidence of elevated neuroinflammatory markers in healthy, non-COVID-19-infected individuals after the lockdown enforced in Massachusetts (as in several other states) starting March 2020. HC POST subjects showed elevations in the brain levels of $\left[{ }^{11} \mathrm{C}\right] \mathrm{PBR} 28$ (measured PET) and mIns (measured using ${ }^{1} \mathrm{H}-\mathrm{MRS}$ ), thus providing multimodal evidence for neuroinflammation in cortical and subcortical regions including sensory, motor and higher order association areas, and white matter. $\left[{ }^{11} \mathrm{C}\right] \mathrm{PBR} 28$ signal elevations were positively associated with physical fatigue (IPS/precuneus), mental fatigue and mood alterations (hippocampus). Collectively, these findings provide support to neuroimmune responses as mechanisms underlying stress, depression and other symptoms of psychological distress. ${ }^{7,24}$ Further, the regional variability in increased $\left[{ }^{11} \mathrm{C}\right] \mathrm{PBR} 28$ signal could be predicted by constitutive expression of genes related to glial neuroimmune response in healthy post-mortem human brains.

Overall, our results indicate that pandemic-associated stressors may have triggered a neuroimmune response in non-infected individuals. 
medRxiv preprint doi: https://doi.org/10.1101/2021.09.21.21263740; this version posted September 27, 2021. The copyright holder for this

It is made available under a CC-BY-NC-ND 4.0 International license .

Although several studies have recently raised the urgent need for research to quantitatively address consequences of COVID-19-related disruptions on human health,, ${ }^{2,3}$ neuroinflammatory responses in non-infected individuals during the pandemic so far have not been explored. However, a wealth of pre-clinical studies has shown that inflammatory processes and social behaviors are deeply connected: as inflammatory processes can affect social behaviors, exposure to chronic stressors can also upregulate inflammation. ${ }^{26}$ Specifically, prolonged stress can lead to an increase in pro- inflammatory cytokines (e.g., Interleukin-6), ${ }^{5,27}$ which in turn may trigger sickness and depressive-like behaviors. ${ }^{9}$ Further, clinical research has provided evidence for neuroinflammation in subjects with major depression ${ }^{11}$ or depressive symptoms comorbid to chronic pain. ${ }^{12}$ Likewise, glial activation has been recently implicated in the pathophysiology of fibromyalgia ${ }^{14}$ and Gulf War Illness, ${ }^{16}$ both conditions characterized by several symptoms including excessive fatigue and "brain fog", which are symptoms reported by many during the pandemic. As such, preclinical and clinical work provide support the investigation of neuroinflammation as a mechanism of the symptoms observed with increasing frequency during the COVID-19 pandemic, -importantly- even among the non-infected.

TSPO is a five-transmembrane domain protein mostly expressed on the outer membrane of mitochondria which is dramatically overexpressed in activated microglia and astrocytes, as well as peripheral immune cells ${ }^{18}$ in the context of neuroinflammatory responses. Indeed, a strong colocalization between TSPO upregulation and activated glial cells has been found across multiple preclinical and human studies of various disorders, including in rodent and human studies of multiple sclerosis, human immunodeficiency encephalitis, ischemia, depression, and Alzheimer's disease. ${ }^{18,22}$ While specificity of TSPO upregulation to glial cells is questioned in other work, the co-occurrence of post-lockdown elevations also in the brain concentration of mIns (a metabolite 
medRxiv preprint doi: https://doi.org/10.1101/2021.09.21.21263740; this version posted September 27, 2021. The copyright holder for this preprint (which was not certified by peer review) is the author/funder, who has granted medRxiv a license to display the preprint in perpetuity.

It is made available under a CC-BY-NC-ND 4.0 International license .

that is more abundant in glial cells rather than other cell types) $)^{19}$ as well as our imaging transcriptomics analyses (which map the TSPO signal increases to the the constitutive architecture of genes implicated in immune/neuroimmune signaling) corroborate a neuroinflammatory interpretation of our imaging findings. Interestingly, our results have shown that the mean thalamic levels of mIns and $\left[{ }^{11} \mathrm{C}\right] \mathrm{PBR} 28$ were not correlated, albeit we did previously observe an association between the two glial markers in patients with amyotrophic lateral sclerosis. ${ }^{28}$ It is possible that changes in $\left[{ }^{11} \mathrm{C}\right] \mathrm{PBR} 28$ and mIns levels observed in our study may reflect distinct neuroinflammatory processes or two elements of a common process with different time courses (as previously suggested). ${ }^{19}$

When interpreting the results of our study, the reader should be mindful of several limitations. First, $\mathrm{HC}_{\mathrm{POST}}$ had a relatively small sample size, particularly compared to the $\mathrm{HC}_{\mathrm{PRE}}$ cohort (a limitation largely imposed by the COVID-19 pandemic-related disruption on clinical research $)^{29}$. However, multiple factors provide high confidence in the solidity of our observations, including the consistency of our observations across individuals, scanners, age groups, genotypes, and sexes (see Appendix, Suppl. Figure 3), the relative stability of the pre-lockdown markers, the observed elevation of two separate imaging markers measured using independent imaging modalities and the finding of significant enrichment in genes highly expressed in glial cells.

Second, our analysis was largely based on unpaired comparisons of pre- and post-lockdown groups. While our single subject scanned both pre- and post-lockdown demonstrated PET signal elevations in the same regions observed in the group comparison, longitudinal assessments of more individuals scanned in the same manner will be needed to better understand the impact of the COVID-19 pandemic on brain health. 
medRxiv preprint doi: https://doi.org/10.1101/2021.09.21.21263740; this version posted September 27, 2021. The copyright holder for this

It is made available under a CC-BY-NC-ND 4.0 International license.

Third, because pandemic-specific questionnaires were not collected at the time of the scan visits, behavioral analyses were conducted using retrospectively collected questionnaire data, and only from a subset of subjects. As such the link between neuroinflammation and clinical symptoms presented in this report should be regarded as preliminary, and will need validation in larger studies.

Irrespective of these limitations, our study presents novel evidence of pandemic-related neuroinflammation in non-infected participants, providing an example of how broad the impact of the pandemic has been on human health, extending beyond the morbidity directly induced by the virus itself. As prolonged inflammation can be implicated in the pathogenesis of a variety of conditions, including breakdown of immune tolerance, ${ }^{30}$ future studies are needed to assess the long-term implications of COVID-19-pandemic related neuroinflammatory responses.

\section{Contributors}

LB conceived the idea for the study, conducted the main study design and validation, undertook the data analysis, wrote and revised the manuscript. ZA contributed to PET data collection, data pre-processing and manuscript revision. MK contributed to PET and clinical data collection, data analysis and manuscript revision. AW contributed to ${ }^{1} \mathrm{H}-\mathrm{MRS}$ data collection and pre-processing, and manuscript content. HH contributed to data analysis and manuscript revision. EJM, PCK, KACB, OJA, NRZ and DSA contributed to data collection. EMR contributed to the study funding, data collection and manuscript revision. CET contributed to manuscript revision. MV, FT and NH contributed to manuscript revision and data interpretation. DM performed the imaging transcriptomics analyses, contributed to data interpretation and manuscript content. BRR 
contributed to data interpretation. The statistician (NDM) contributed to data analysis. JMH contributed to study funding. The corresponding author (MLL) contributed to study funding, data collection, supervised data analysis and data interpretation and contributed to writing the manuscript. All authors approved the manuscript and had final responsibility for the decision to submit for publication. LB and MLL had full access to and verified the underlying data. The study results were shared with all study team members through online presentations. All authors had the opportunity to contribute to the data interpretation and manuscript content through helpful discussions and written communications. All authors have read and approved the final manuscript.

\section{Declaration of interests}

All authors declare no competing interests.

\section{Data sharing}

Following publication of the study results, data will be made available upon reasonable request.

\section{Ethics approval and consent to participate}

The Institutional Review Board (IRB) of Mass General Brigham (MGB) gave ethical approval to this study. Written informed consent was obtained from all participants before enrollment according to the ethical standards of the 1964 Helsinki declaration. 
medRxiv preprint doi: https://doi.org/10.1101/2021.09.21.21263740; this version posted September 27, 2021. The copyright holder for this preprint (which was not certified by peer review) is the author/funder, who has granted medRxiv a license to display the preprint in perpetuity. It is made available under a CC-BY-NC-ND 4.0 International license .

\section{Acknowledgments}

The authors would like to thank Dr. Ciprian Catana and Dr. Julie Price for helpful discussion on data quality control, and Angel Torrado-Carvajal, Atreyi Saha, Courtney Bergan and Yang Lin for help with data collection. We also thank Grae Arabasz, Regan Butterfield and Shirley

Hsu and all the A.A. Martinos Radiochemistry team for producing and administering the radioligand. 


\section{Tables and Figures}

$\begin{array}{lllll} & & \text { HCPRE } & \text { HCPOST } & \text { p } \\ \mathrm{N} & & 57 & 15 & \\ \text { Sex } & \text { Male } & 30(52.6) & 12(80) & 0.06 \\ \text { Age }[\mathrm{y}] & \text { Female } & 27(47.4) & 3(20) & <0.01 \\ \text { TSPO genotype } & \text { HAB } & 42.85(15.36) & 60.73(10.7) & 0.43 \\ & \text { MAB } & 24(57.9) & 7(46.6) & \\ \text { Scanner } & \text { Scanner 1 } & 44(77.2) & 8(53.4) & 0.17 \\ \text { Weight }[\mathrm{kg}] & \text { Scanner 2 } & 13(22.8) & 9(60) & 0.37 \\ \text { Inj. dose }[\mathrm{mCi}] & & 73.71(16.0) & 7(40) & 0.21\end{array}$

Table 1. Demographics from the main $\left[{ }^{11} \mathrm{C}\right]$ PBR28 PET cohorts $\left(\mathrm{HC}_{\text {Post }}\right.$ vs HC $\mathrm{CRE}_{\text {) }}$. Categorical variables are summarized as frequencies (proportions) and continuous variables are summarized as mean (standard deviation). $\mathrm{HAB}=$ high affinity binders; $\mathrm{MAB}=$ mixed affinity binders; $\mathrm{mCi}=$ millicuries. 
medRxiv preprint doi: https://doi.org/10.1101/2021.09.21.21263740; this version posted September 27, 2021. The copyright holder for this preprint (which was not certified by peer review) is the author/funder, who has granted medRxiv a license to display the preprint in perpetuity.

It is made available under a CC-BY-NC-ND 4.0 International license .

\begin{tabular}{|c|c|c|c|c|}
\hline & & HC & HCPOST & $\mathbf{p}$ \\
\hline $\mathrm{N}$ & & 13 & 11 & \\
\hline \multirow{2}{*}{ Sex } & Male & $7(53.8)$ & $8(72.7)$ & \multirow{2}{*}{0.34} \\
\hline & Female & $6(46.2)$ & $3(27.3)$ & \\
\hline Age [y] & & $46.34(13.51)$ & $60.36(12.2)$ & $<0.05$ \\
\hline \multirow{2}{*}{ Scanner } & Scanner 1 & $2(15.4)$ & $6(54.5)$ & \multirow{2}{*}{$<0.05$} \\
\hline & Scanner 2 & $11(84.6)$ & $5(45.5)$ & \\
\hline Weight [kg] & & 77.4(11.69) & $76.73(22.61)$ & 0.92 \\
\hline
\end{tabular}

Table 2 Demographics from the main ${ }^{1} \mathrm{H}-\mathrm{MRS}$ cohorts (HC $\left.\mathrm{HOST}_{\mathrm{PS}} \mathrm{HC}_{\mathrm{PRE}}\right)$. Categorical variables are summarized as frequencies (proportions) and continuous variables are summarized as mean (standard deviation). 
medRxiv preprint doi: https://doi.org/10.1101/2021.09.21.21263740; this version posted September 27, 2021. The copyright holder for this preprint (which was not certified by peer review) is the author/funder, who has granted medRxiv a license to display the preprint in perpetuity.

It is made available under a CC-BY-NC-ND 4.0 International license .

\begin{tabular}{|c|c|c|c|c|c|c|}
\hline \multirow{2}{*}{$\begin{array}{l}\text { Cluster size } \\
\text { (\# voxels) }\end{array}$} & \multirow{2}{*}{$\begin{array}{l}\text { Cluster } \\
\text { p-value }\end{array}$} & \multicolumn{4}{|c|}{ Peak } & \multirow[t]{2}{*}{ Anatomical Location } \\
\hline & & $\mathrm{Z}$ & $\mathrm{x}$ & $\mathrm{y}$ & $\mathrm{z}$ & \\
\hline \multicolumn{7}{|c|}{$\mathrm{HC}_{\mathrm{POST}}>\mathrm{HC}_{\mathrm{PRE}}$} \\
\hline \multirow[t]{19}{*}{31504} & 0.0006 & 3.54 & -20 & -36 & -1 & L Hippocampus \\
\hline & & 3.54 & -6 & 2 & 57 & $\begin{array}{l}\text { L Supplementary Motor } \\
\text { Cortex }\end{array}$ \\
\hline & & 3.54 & 10 & 5 & 36 & R Anterior Cingulate Cortex \\
\hline & & 3.54 & -40 & -23 & 37 & L Postcentral Gyrus \\
\hline & & 3.54 & -32 & -7 & 46 & L Precentral Gyrus \\
\hline & & 3.54 & -29 & -47 & 43 & L Superior Parietal Lobe \\
\hline & & 3.54 & -40 & 4 & -6 & L Anterior Insula \\
\hline & & 3.54 & -19 & -27 & 54 & L White Matter \\
\hline & & 3.54 & -9 & 11 & -12 & L Nucleus Accumbens \\
\hline & & 3.54 & 7 & 23 & -16 & R Subcallosal Cortex \\
\hline & & 3.54 & -46 & 6 & 17 & L Inferior Frontal Gyrus \\
\hline & & 3.54 & -25 & 3 & 0 & L Putamen \\
\hline & & 3.35 & -20 & 8 & 48 & L Superior Frontal Gyrus \\
\hline & & 3.23 & -16 & 6 & -22 & L Frontal Orbital Cortex \\
\hline & & 3.23 & -37 & -22 & 1 & L Posterior Insula \\
\hline & & 3.23 & 4 & -5 & 0 & R Thalamus \\
\hline & & 3.09 & 35 & -1 & 55 & L Middle Frontal Gyrus \\
\hline & & 3.03 & 22 & -4 & -24 & R Amygdala \\
\hline & & 2.98 & 18 & -53 & 25 & R Precuneus Cortex \\
\hline
\end{tabular}

$\mathrm{HC}_{\text {PRE }}>\mathrm{HC}_{\text {POST }}$

n.s.

Table 3. Peak coordinates from brain regions significant in whole-brain $\left[{ }^{11} \mathrm{C}\right] \mathrm{PBR} 28$ PET voxel-wise group analyses. 


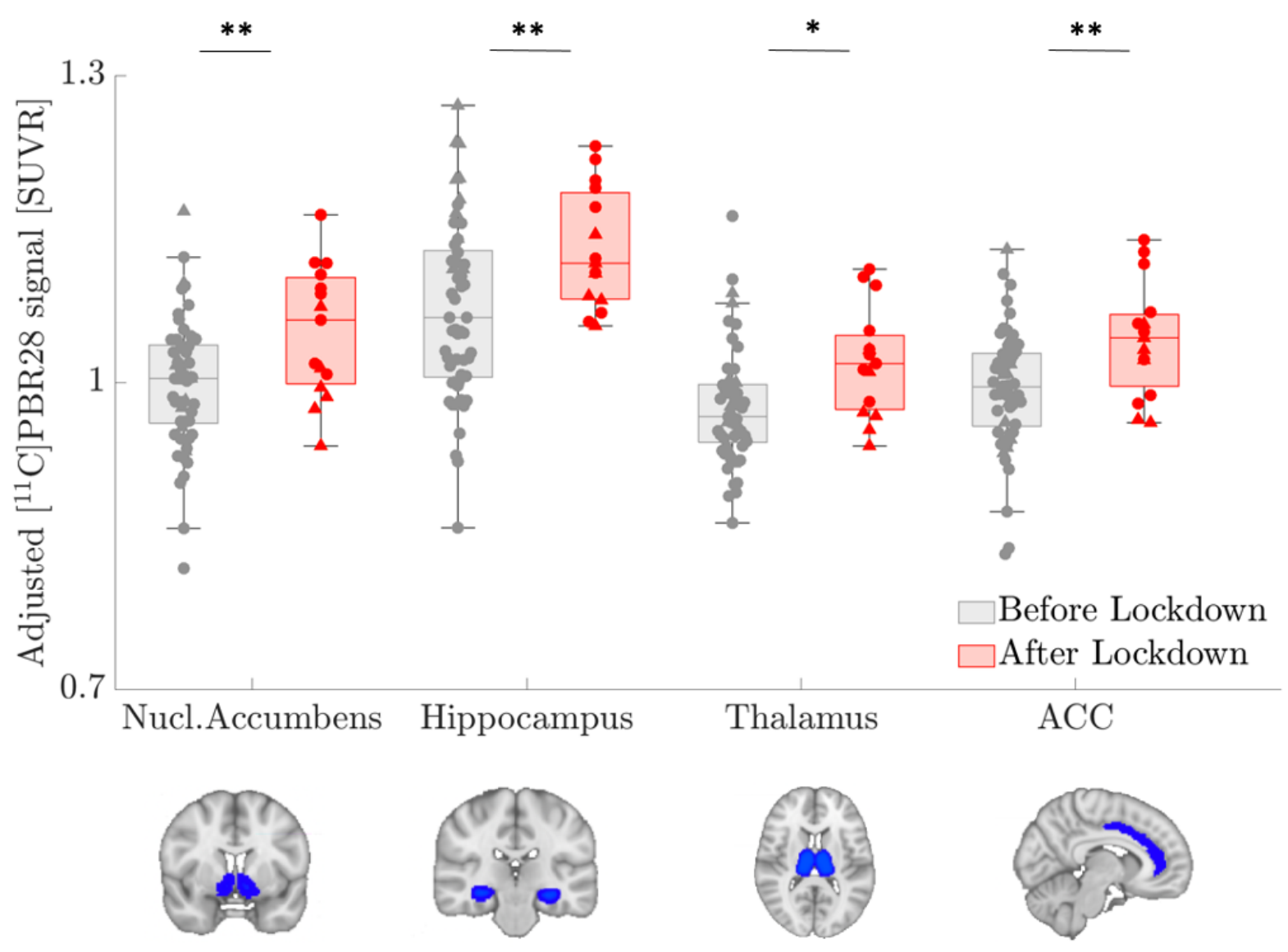

Figure 1. Post-lockdown $\left[{ }^{11} \mathrm{C}\right]$ PBR28 PET signal elevations in ROI group analyses. Group comparison of $\left[{ }^{11} \mathrm{C}\right] \mathrm{PBR} 28$ PET data collected before (HC $\mathrm{PRE}$ ) or after lockdown (HCPOST), in apriori ROIs. Standardized uptake value ratio (SUVR) adjusted for age, TSPO polymorphism, and scanner is displayed. $\mathrm{ACC}=$ Anterior Cingulate Cortex. Error bars denote 25th to 75 th inter-quartile range, and the horizontal line represents the median. Triangles denote data from Scanner 1 and circles denote data from Scanner $2 .^{*}=\mathrm{p}<0.05$, corrected; $* *=\mathrm{p}<0.01$, corrected. 
medRxiv preprint doi: https://doi.org/10.1101/2021.09.21.21263740; this version posted September 27, 2021. The copyright holder for this preprint (which was not certified by peer review) is the author/funder, who has granted medRxiv a license to display the preprint in perpetuity.

It is made available under a CC-BY-NC-ND 4.0 International license .

$\mathbf{A}$

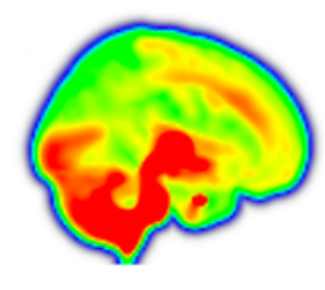

HC $_{\text {PRE }}$

B
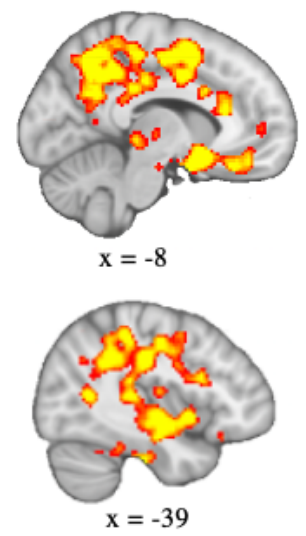

$\mathrm{HC}_{\mathrm{POST}}>\mathrm{HC}_{\mathrm{PRE}}$ p(cluster-corrected)

C

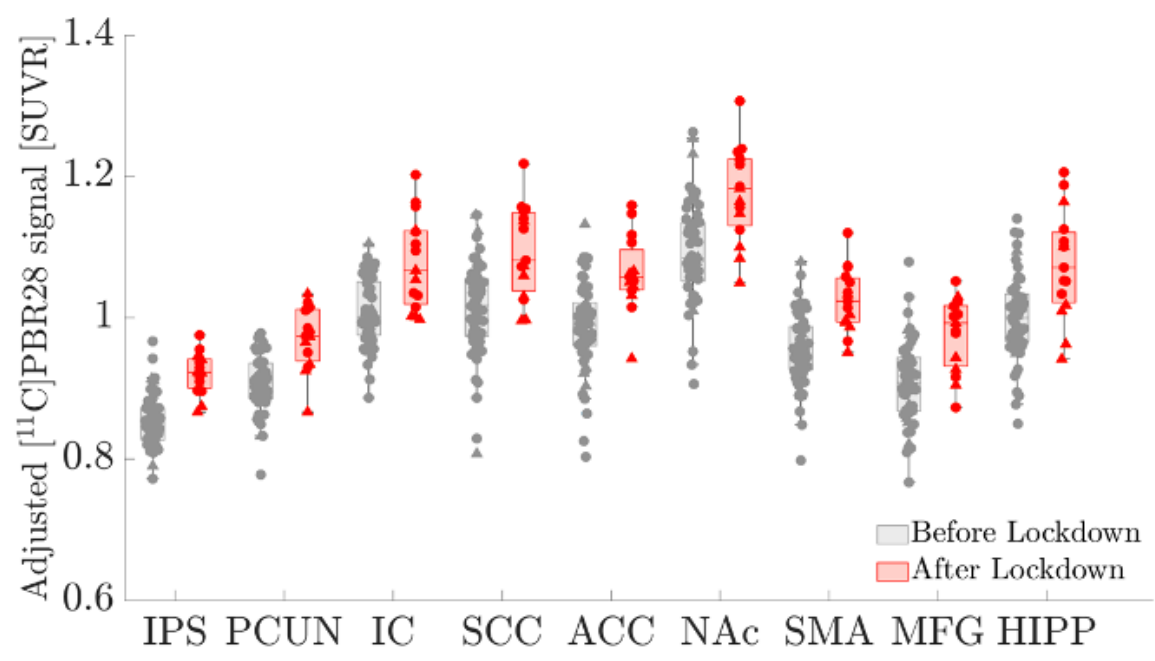

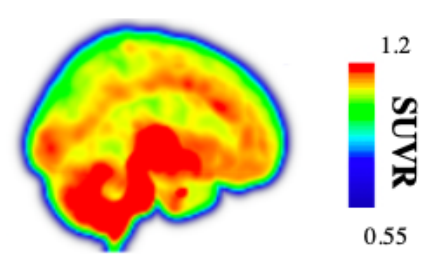

HC $_{\text {POST }}$

$\mathrm{N}=15$

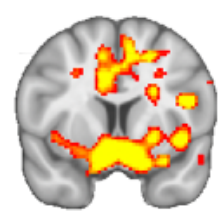

$y=+8$

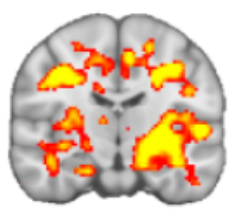

$y=-14$

$\mathrm{HC}_{\text {PRE }}>\mathrm{HC}_{\text {POST }}$ p(cluster-corrected)

0.01
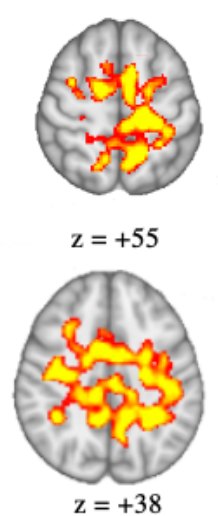

0.001 $\mathrm{z}=+55$

Figure 2. Post-lockdown $\left[{ }^{11}\right.$ C]PBR28 PET signal elevations in voxelwise group analyses. Areas of elevated PET $\left[{ }^{11} \mathrm{C}\right] \mathrm{PBR} 28$ signal (SUVR) in $\mathrm{HC}_{\mathrm{POST}}$ subjects compared to HCPRE 
subjects. (A) Mean images computed from $57 \mathrm{HC}_{\mathrm{PRE}}$ and $15 \mathrm{HC}_{\mathrm{POST}}$ subjects are displayed as maximum intensity projections. (B) Significant cluster from the $\mathrm{HC}_{\mathrm{POST}}>\mathrm{HC}_{\mathrm{PRE}}$ voxel-wise contrast is shown in a red-yellow color scale. There were no significant regions for the $\mathrm{HC}_{\mathrm{PRE}}>$

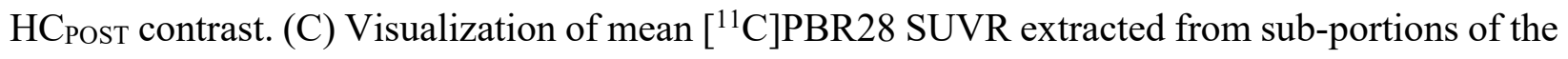
cluster statistically significant in A. IPS=Intraparietal Sulcus, PCUN=Precuneus, IC=Insular Cortex, $\mathrm{SCC}=$ Subcallosal Cortex, $\mathrm{ACC}=$ Anterior Cingulate Cortex, NAc $=$ Nucleus Accumbens, $\mathrm{SMA}=$ Supplementary Motor Area, $\mathrm{MFG=Middle} \mathrm{Frontal} \mathrm{Gyrus,} \mathrm{HIPP=Hippocampus.} \mathrm{Error} \mathrm{bars}$ denote 25 th to 75 th inter-quartile range. Triangles denote data from Scanner 1 and circles denote data from Scanner 2. 
$\mathbf{A}$

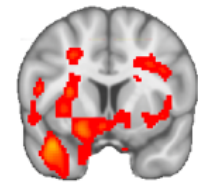

$y=+8$

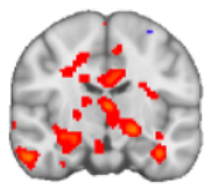

$\mathrm{y}=-14$

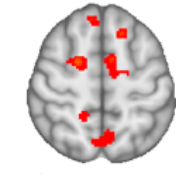

$\mathrm{z}=+55$

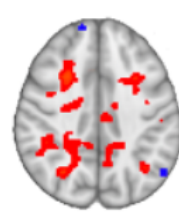

$\mathrm{z}=+38$

Difference (POST - PRE)

[11C]PBR28 signal (SUVR)

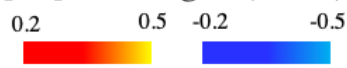

B

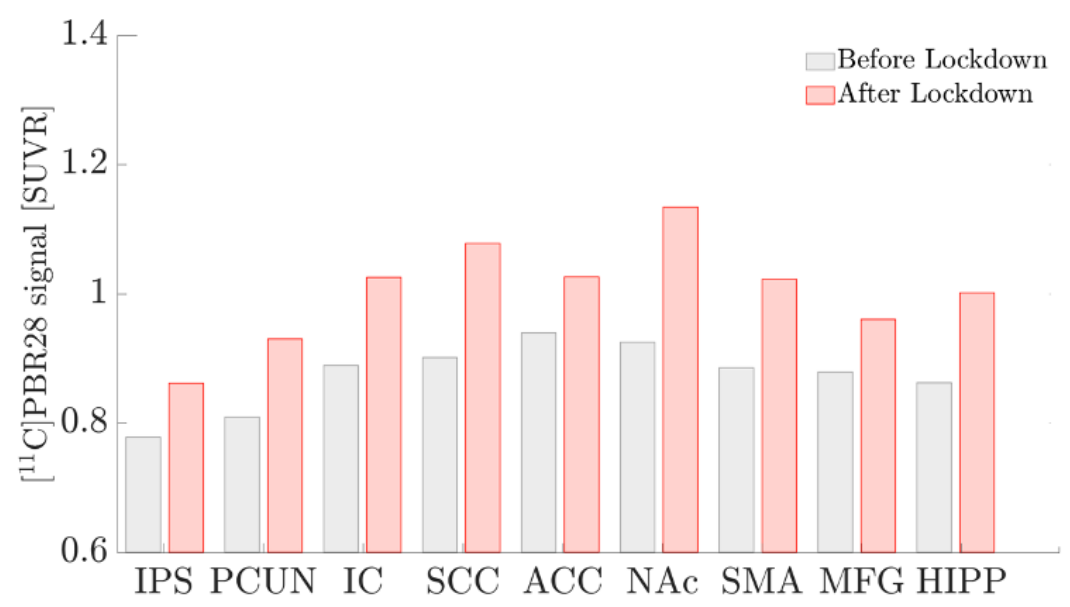

Figure 3. Within-subject post-lockdown $\left[{ }^{11}\right.$ C]PBR28 PET signal elevations. Case study of one subject scanned before (September 2016) and after lockdown (October 2020) in Scanner 1. (A) Difference image (post-pre) reported in red-yellow and cyan-blue color bars. (B) Bar graph of mean $\left[{ }^{11} \mathrm{C}\right] \mathrm{PBR} 28$ SUVR extracted from sub-portions of the cluster statistically significant in the main voxelwise group analyses. See Figure 2 caption for abbreviations. 
medRxiv preprint doi: https://doi.org/10.1101/2021.09.21.21263740; this version posted September 27, 2021. The copyright holder for this preprint (which was not certified by peer review) is the author/funder, who has granted medRxiv a license to display the preprint in perpetuity.

It is made available under a CC-BY-NC-ND 4.0 International license .

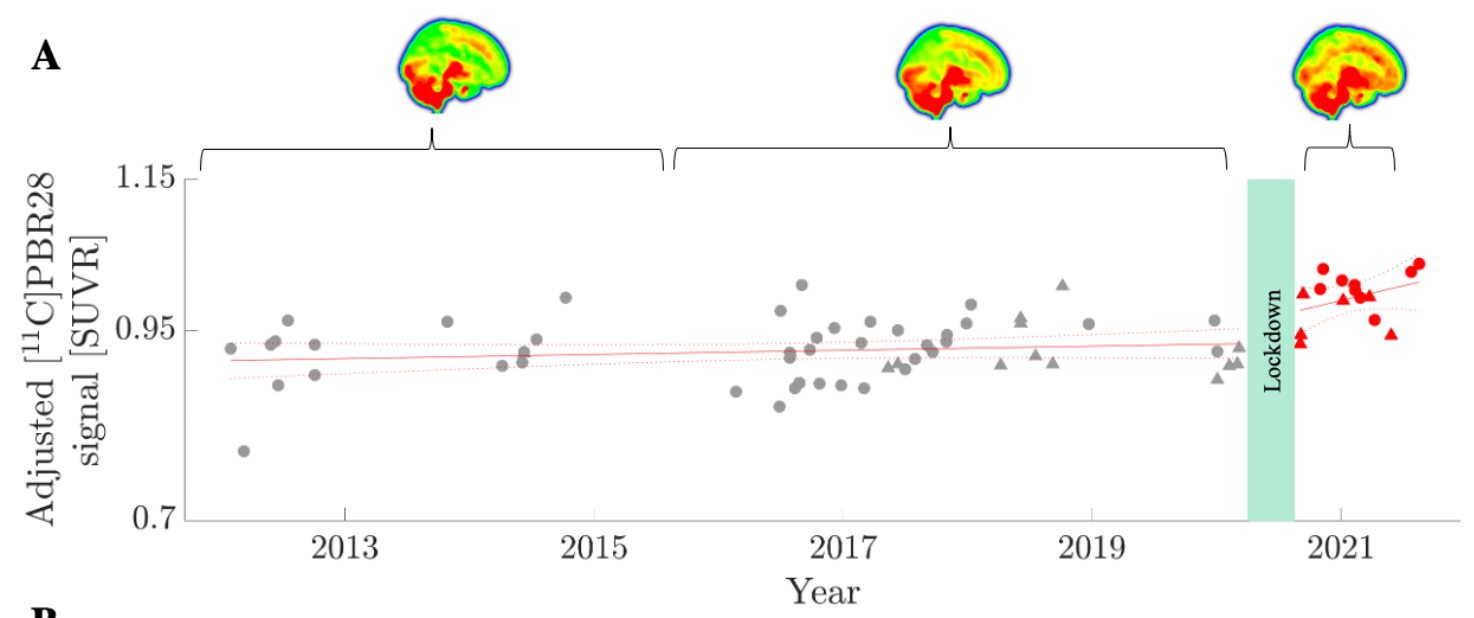

\section{B}

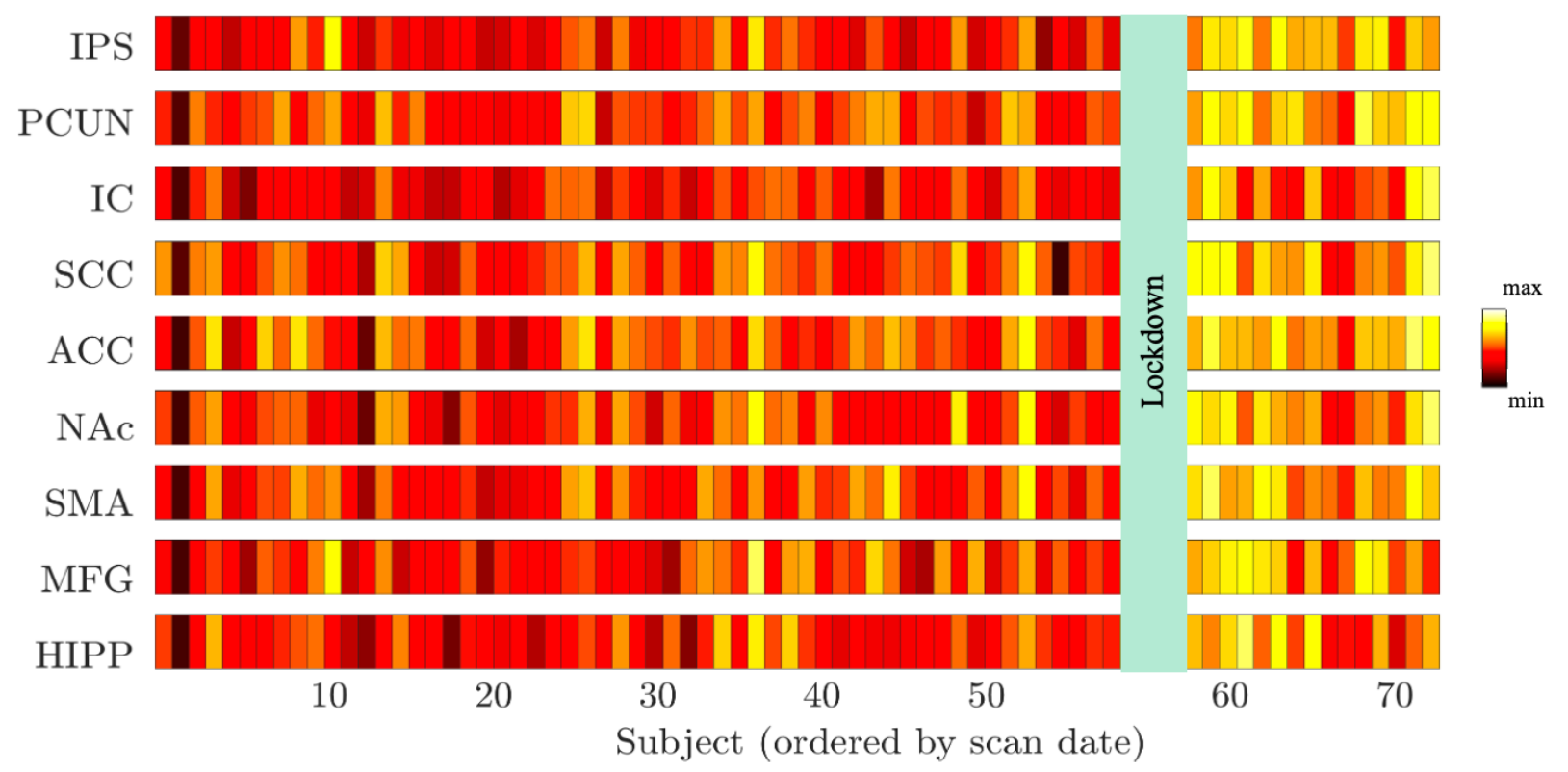

Figure 4. $\left[{ }^{11} \mathrm{C}\right]$ PBR28 PET signal across time. (A) $\left[{ }^{11} \mathrm{C}\right] \mathrm{PBR} 28$ signal (SUVR) extracted from the cluster significant in the main voxelwise group analyses, adjusted for scanner, age and TSPO polymorphism, and plotted against scan date. Triangles denote data from Scanner 1 and circles denote data from Scanner 2. Linear regression model fit is overlayed to display mean trend over time for each group. Maximum intensity projection from mean images computed from subjects scanned between 2012 and 2015, between 2016 and 02/2020 and after 08/2020 are displayed above the plot for illustrative purposes. (B) Mean $\left[{ }^{11} \mathrm{C}\right] \mathrm{PBR} 28$ SUVR extracted from sub-portions of the 
medRxiv preprint doi: https://doi.org/10.1101/2021.09.21.21263740; this version posted September 27, 2021. The copyright holder for this preprint (which was not certified by peer review) is the author/funder, who has granted medRxiv a license to display the preprint in perpetuity. It is made available under a CC-BY-NC-ND 4.0 International license .

cluster statistically significant in the main voxelwise group analyses, and sorted by scan date. The range of the color scale was set for each region independently to best illustrate the post-lockdown PET signal increase, for visualization purposes. See Figure 2 caption for abbreviations. 


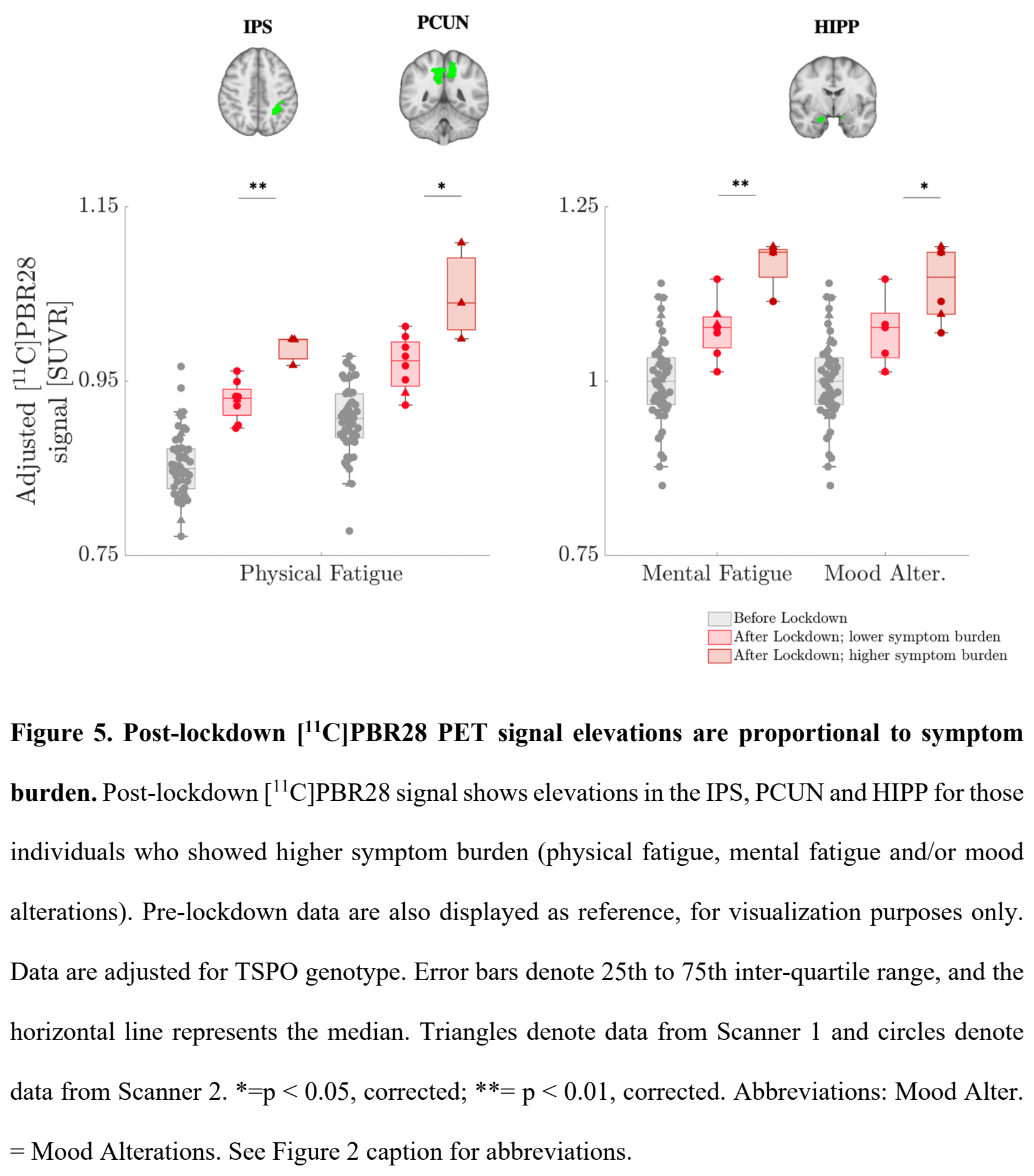


medRxiv preprint doi: https://doi.org/10.1101/2021.09.21.21263740; this version posted September 27, 2021. The copyright holder for this preprint (which was not certified by peer review) is the author/funder, who has granted medRxiv a license to display the preprint in perpetuity.

It is made available under a CC-BY-NC-ND 4.0 International license .
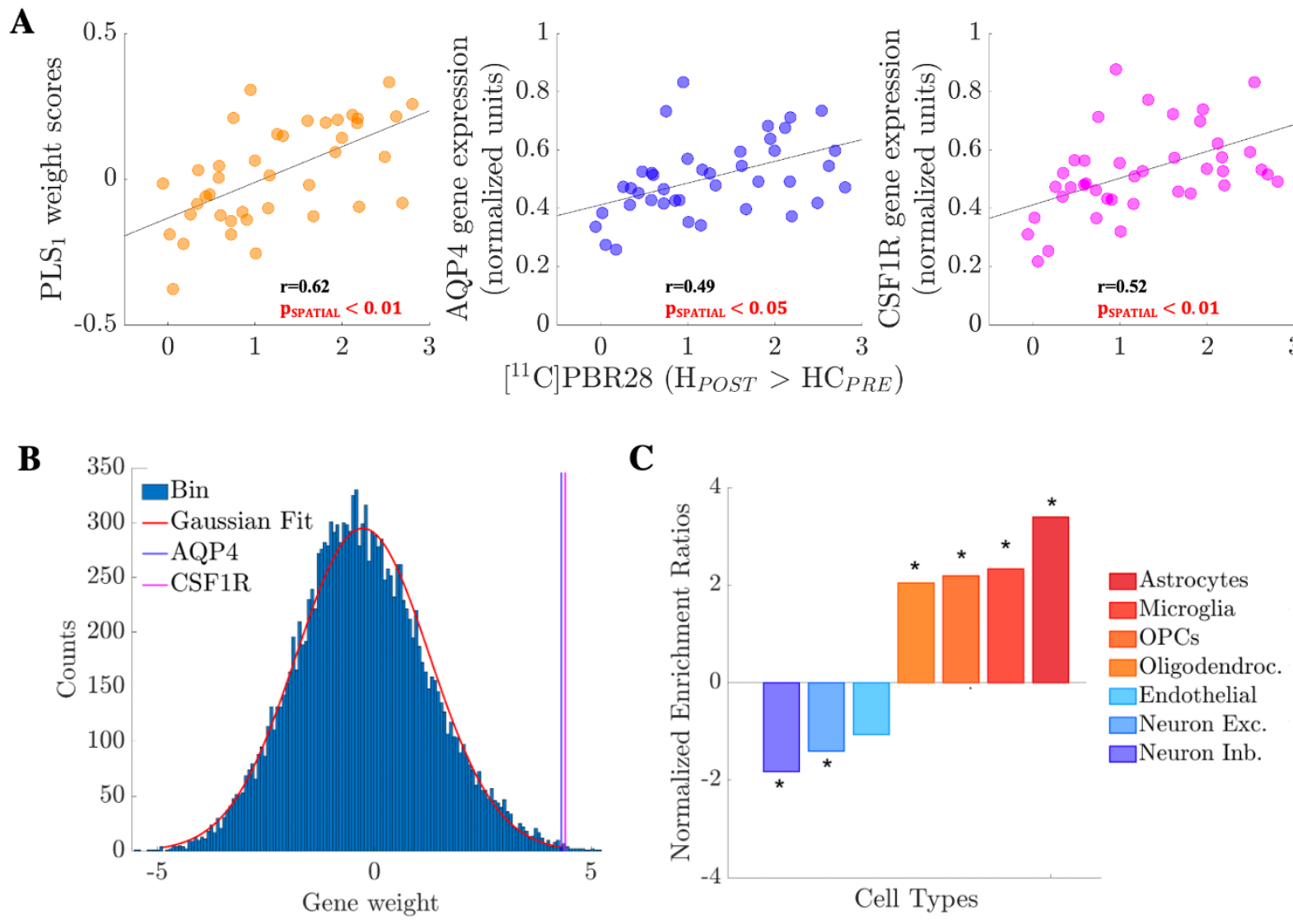

Figure 6. Imaging transcriptomics analyses. (A) First component of the PLS analyses (PLS1; weight scores), AQP4 (astrocyte marker) and CSF1R (microglia marker) gene expression (normalized units) plotted against $\left[{ }^{11} \mathrm{C}\right] \mathrm{PBR} 28$ contrast $\mathrm{t}$-stat $\left(\mathrm{HC}_{\mathrm{POST}}>\mathrm{HC} \mathrm{CRE}_{\mathrm{PRE}}\right)$ in the 41 regions of left hemisphere regions (34 cortical plus 7 subcortical regions) of the Desikan-Killiany atlas. Genes with positive weights in $\mathrm{PLS}_{1}$ have higher-than-average expression where $\left[{ }^{11} \mathrm{C}\right] \mathrm{PBR} 28$ showed the largest post-lockdown increases and lower-than-average expression in regions with minimal changes. Of note, pSPATIAL is obtained via spatial permutation testing (spin test) to account for the inherent spatial autocorrelation of the imaging data (see Appendix). (B) Histogram (150 bins) of gene weights in PLS 1 with the highly-ranked positions of AQP4 and CSF1R highlighted (scores 4.31 and 4.40 respectively). (C) Brain cell-type gene set enrichment analysis. Positive normalized enrichment ratios (in orange-red shades) indicate enrichment for genes of a certain 
medRxiv preprint doi: https://doi.org/10.1101/2021.09.21.21263740; this version posted September 27, 2021. The copyright holder for this preprint (which was not certified by peer review) is the author/funder, who has granted medRxiv a license to display the preprint in perpetuity. It is made available under a CC-BY-NC-ND 4.0 International license .

cell-type among those genes with high expression in regions with the largest post-lockdown increases in $\left[{ }^{11} \mathrm{C}\right] \mathrm{PBR} 28$ signal (positive weights in $\mathrm{PLS}_{1}$ ). Negative normalized enrichment ratios (in blue shades) indicate enrichment for genes of a certain cell-type among genes with high expression in regions with minimal or negligible increases in $\left[{ }^{11} \mathrm{C}\right] \mathrm{PBR} 28$ signal (negative weights in PLS1). ${ }^{*}=\mathrm{p}<0.05$, after FDR correction for the total number of cell-types tested. Abbreviations: OPCs= Oligodendrocyte Precursor Cells; Oligodendroc. $=$ Oligodendrocytes; Neuron Exc. $=$ Excitatory Neurons; Neuron Inb. = Inhibitory Neurons. 
A

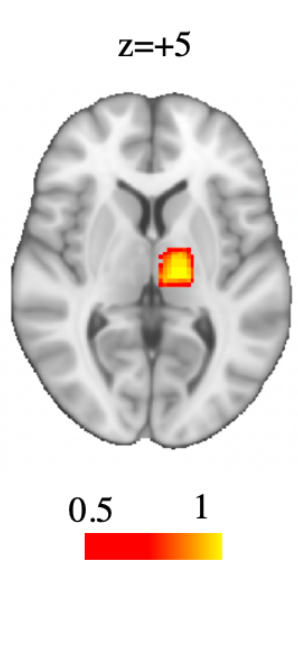

B

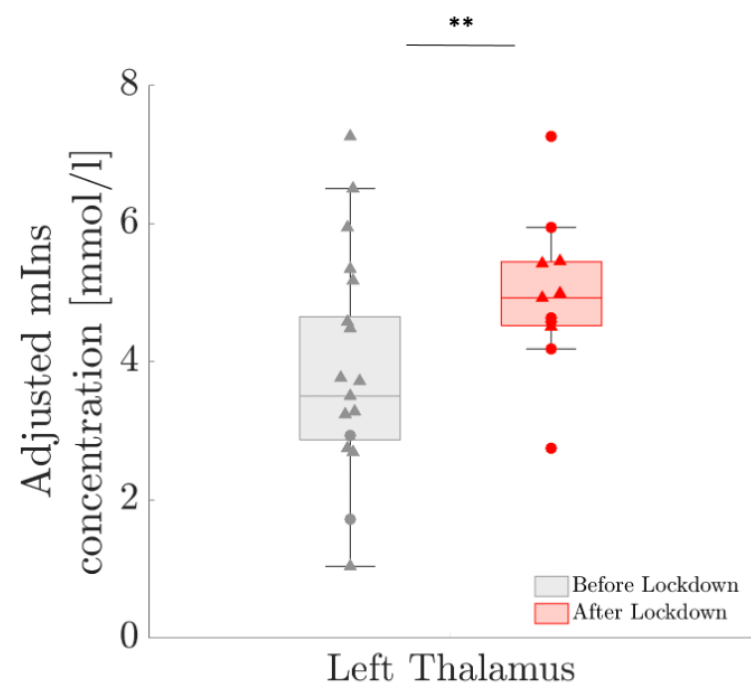

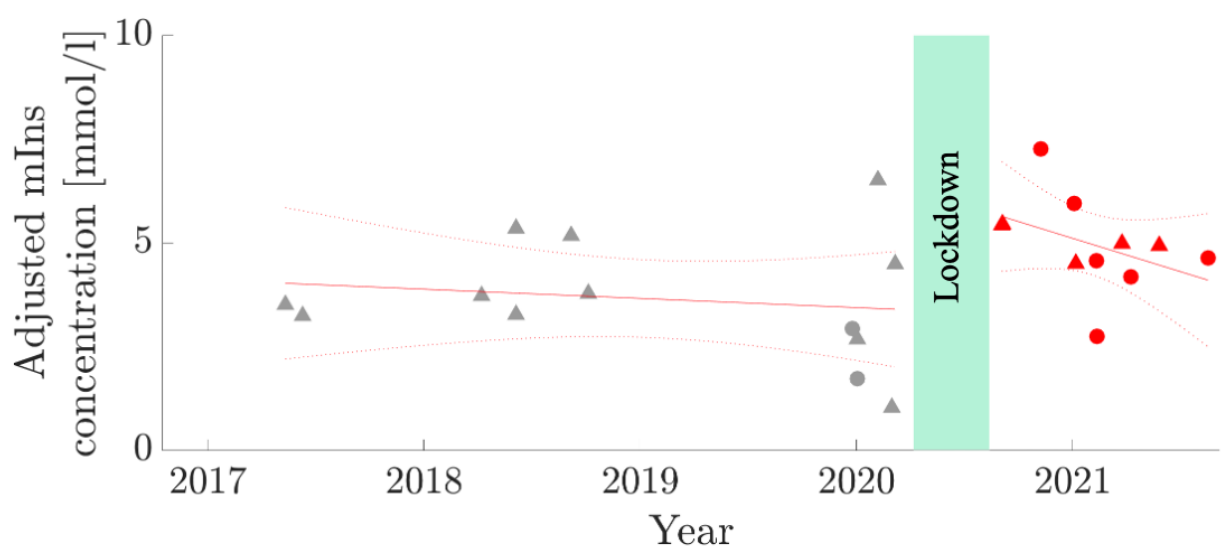

Figure 7. Post-lockdown elevations in ${ }^{1} \mathrm{H}-\mathrm{MRS}$-measured myoinositol concentration. (A) Probabilistic map of thalamic voxel placement in standard space, calculated via non-linear transformation between each subjects' MPRAGE volume and MNI151 template, then applied to the MRS voxel. (B) Group comparison of mIns concentration in the left thalamus. Error bars denote 25 th to 75 th inter-quartile range. Triangles denote data from Scanner 1 and circles denote data from Scanner 2. (C) mIns concentration in the left thalamus plotted against scan date. Displayed values are adjusted for scanner and age. 


\section{Bibliography}

1. CDC, National Center for Health Statistics. Indicators of anxiety or depression based on reported frequency of symptoms during the last 7 days. Household Pulse Survey. US Department of Health and Human Services, CDC, National Center for Health Statistics; 2020.

2. Holmes EA, O'Connor RC, Perry VH, et al. Multidisciplinary research priorities for the COVID-19 pandemic: a call for action for mental health science. The Lancet Psychiatry 2020; 7(6): 547-60.

3. Gonçalves de Andrade E, Šimončičová E, Carrier M, Vecchiarelli HA, Robert M-È, Tremblay M-È. Microglia Fighting for Neurological and Mental Health: On the Central Nervous System Frontline of COVID-19 Pandemic. Frontiers in Cellular Neuroscience 2021; 15(12).

4. Kar Ray M, Chow KK, Theodoros T, et al. LOVE in the time of Covid-19: a brief mental health intervention to overcome loneliness. Australas Psychiatry 2021: 10398562211010806.

5. Smith KJ, Gavey S, RIddell NE, Kontari P, Victor C. The association between loneliness, social isolation and inflammation: a systematic review and meta-analysis. Neuroscience \& Biobehavioral Reviews 2020; 112: 519-41.

6. Stein DJ, Vasconcelos MF, Albrechet-Souza L, Ceresér KM, De Almeida RM. Microglial over-activation by social defeat stress contributes to anxiety-and depressive-like behaviors. Frontiers in behavioral neuroscience 2017; 11: 207.

7. Calcia MA, Bonsall DR, Bloomfield PS, Selvaraj S, Barichello T, Howes OD. Stress and neuroinflammation: a systematic review of the effects of stress on microglia and the implications for mental illness. Psychopharmacology (Berl) 2016; 233(9): 1637-50.

8. Eisenberger NI, Moieni M, Inagaki TK, Muscatell KA, Irwin MR. In Sickness and in Health: The Co-Regulation of Inflammation and Social Behavior. Neuropsychopharmacology 2017; 42(1): 242-53.

9. Dantzer R. Cytokine, sickness behavior, and depression. Immunol Allergy Clin North Am 2009; 29(2): 247-64.

10. Fleshner M, Frank M, Maier SF. Danger Signals and Inflammasomes: Stress-Evoked Sterile Inflammation in Mood Disorders. Neuropsychopharmacology 2017; 42(1): 36-45.

11. Setiawan E, Attwells S, Wilson AA, et al. Association of translocator protein total distribution volume with duration of untreated major depressive disorder: a cross-sectional study. Lancet Psychiatry 2018; 5(4): 339-47.

12. Albrecht DS, Kim M, Akeju O, et al. The neuroinflammatory component of negative affect in patients with chronic pain. Mol Psychiatry 2021; 26(3): 864-74.

13. Troubat R, Barone P, Leman S, et al. Neuroinflammation and depression: A review. Eur J Neurosci 2021; 53(1): 151-71.

14. Albrecht DS, Forsberg A, Sandström A, et al. Brain glial activation in fibromyalgia - A multi-site positron emission tomography investigation. Brain Behav Immun 2019; 75: 72-83.

15. Nakatomi Y, Mizuno K, Ishii A, et al. Neuroinflammation in Patients with Chronic Fatigue Syndrome/Myalgic Encephalomyelitis: An ${ }^{11} \mathrm{C}-(\mathrm{R})-\mathrm{PK} 11195$ PET Study. J Nucl Med 2014; 55(6): 945-50.

16. Alshelh Z, Albrecht DS, Bergan C, et al. In-vivo imaging of neuroinflammation in veterans with Gulf War illness. Brain Behav Immun 2020; 87: 498-507.

17. Dzierzewski JM, Donovan EK, Kay DB, Sannes TS, Bradbrook KE. Sleep Inconsistency and Markers of Inflammation. Frontiers in Neurology 2020; 11(1042). 
It is made available under a CC-BY-NC-ND 4.0 International license .

18. Cosenza-Nashat M, Zhao ML, Suh HS, et al. Expression of the translocator protein of 18 $\mathrm{kDa}$ by microglia, macrophages and astrocytes based on immunohistochemical localization in abnormal human brain. Neuropathol Appl Neurobiol 2009; 35(3): 306-28.

19. Datta G, Violante IR, Scott G, et al. Translocator positron-emission tomography and magnetic resonance spectroscopic imaging of brain glial cell activation in multiple sclerosis. Mult Scler 2017; 23(11): 1469-78.

20. Hawrylycz MJ, Lein ES, Guillozet-Bongaarts AL, et al. An anatomically comprehensive atlas of the adult human brain transcriptome. Nature 2012; 489(7416): 391-9.

21. Owen DR, Guo Q, Rabiner EA, Gunn RN. The impact of the rs6971 polymorphism in TSPO for quantification and study design. Clinical and Translational Imaging 2015; 3(6): 41722.

22. Albrecht DS, Granziera C, Hooker JM, Loggia ML. In Vivo Imaging of Human Neuroinflammation. ACS Chem Neurosci 2016; 7(4): 470-83.

23. Menard C, Pfau ML, Hodes GE, et al. Social stress induces neurovascular pathology promoting depression. Nature Neuroscience 2017; 20(12): 1752-60.

24. DiSabato DJ, Nemeth DP, Liu X, et al. Interleukin-1 receptor on hippocampal neurons drives social withdrawal and cognitive deficits after chronic social stress. Mol Psychiatry 2020. 25. Kang L, Zhang A, Sun N, et al. Functional connectivity between the thalamus and the primary somatosensory cortex in major depressive disorder: a resting-state fMRI study. $B M C$ Psychiatry 2018; 18(1): 339.

26. Liu YZ, Wang YX, Jiang CL. Inflammation: The Common Pathway of Stress-Related Diseases. Front Hum Neurosci 2017; 11: 316.

27. Jaremka LM, Fagundes CP, Peng J, et al. Loneliness promotes inflammation during acute stress. Psychol Sci 2013; 24(7): 1089-97.

28. Ratai EM, Alshikho MJ, Zürcher NR, et al. Integrated imaging of [(11)C]-PBR28 PET, MR diffusion and magnetic resonance spectroscopy (1)H-MRS in amyotrophic lateral sclerosis. Neuroimage Clin 2018; 20: 357-64.

29. Mitchell EJ, Ahmed K, Breeman S, et al. It is unprecedented: trial management during the COVID-19 pandemic and beyond. Trials 2020; 21(1): 784.

30. Furman D, Campisi J, Verdin E, et al. Chronic inflammation in the etiology of disease across the life span. Nat Med 2019; 25(12): 1822-32. 